Wydziat Nauk Ekonomicznych i Zarzadzania UMK

Katedra Marketingu i Zarzadzania Agrobiznesem

\author{
Justyna Łapińska
}

\title{
KONKURENCYJNOŚĆ CZESKIEJ GOSPODARKI W ŚWIETLE RANKINGÓW MIĘDZYNARODOWYCH
}

Zarys treści. W światowych rankingach konkurencyjności Republika Czeska jest oceniana wyżej niż inne kraje, które przeszły transformację systemową i stały się członkiem Unii Europejskiej. Według Światowego Forum Ekonomicznego Czechy były w 2008 r. trzydziestą trzecią gospodarką świata (na 134 kraje podlegające ocenie), według Międzynarodowego Instytutu Rozwoju Zarządzania, dwudziestą ósmą (oceniano 55 krajów). Korzystny wpływ na konkurencyjność gospodarki czeskiej mają takie obszary, jak: innowacje, kształcenie na poziomie podstawowym i wyższym, doskonalenie zawodowe. Pozycja Czech byłaby znacznie wyższa, gdyby nie słabości, jakie ujawniły się w niektórych z badanych kategorii. Dotyczą one przede wszystkim infrastruktury technicznej oraz otoczenia instytucjonalnego. Stosunkowo nisko oceniana jest także jakość sektora usług finansowych oraz stabilność makroekonomiczna.

Słow a kluc zowe : konkurencyjność, rankingi konkurencyjności.

\section{WPROWADZENIE}

Wraz z postępującymi w świecie procesami globalizacji i integracji problemy konkurencyjności gospodarek oraz funkcjonujących w nich przedsiębiorstw nabierają coraz większego znaczenia, stając się przy tym przedmiotem wielu badań naukowych i teoretycznych uogólnień.

W literaturze przedmiotu podkreśla się, iż konkurencyjność jest kategorią, która może być różnie interpretowana, w zależności od tego, czy badaniu podlega sytuacja całej gospodarki, regionów gospodarczych, gałęzi gospodarki narodowej, czy też poszczególnych przedsiębiorstw. 
W niniejszym opracowaniu podjęto próbę ukazania profilu konkurencyjnego kraju, który podobnie jak Polska, przeszedł drogę transformacji systemowej i stał się członkiem Unii Europejskiej - Republiki Czeskiej. Głównym źródłem danych i informacji o gospodarce czeskiej były rankingi konkurencyjności publikowane przez Światowe Forum Ekonomiczne (World Economic Forum - WEF) i Międzynarodowy Instytut Rozwoju Zarządzania (International Management Development - IMD) oraz Roczniki Konkurencyjności Republiki Czeskiej wydawane przez czeskie Centrum Studiów Ekonomicznych (Centrum Ekonomických Studii).

\section{MIĘDZYNARODOWA KONKURENCYJNOŚĆ GOSPODARKI - ASPEKTY TEORETYCZNE}

W literaturze przedmiotu podkreśla się, iż w odniesieniu do pojęcia międzynarodowej konkurencyjności gospodarki nastapiło w ostatnich latach ogromne zainteresowanie, owocujące bogactwem podejść i interpretacji ${ }^{1}$. Według Bossaka i Bieńkowskiego, „konkurencyjność kraju [...] oceniamy poprzez porównanie osiąganych korzyści z działalności gospodarczej z tymi, jakie uzyskują konkurenci; $[\ldots]$ konkurencyjność kraju związana jest z poziomem rozwoju i strukturą gospodarczą i waha się w granicach wyznaczonych przez ich względne koszty, jakość i innowacyjność oraz stan równowagi ekonomicznej”2. Konkurencyjność można pojmować także jako zdolność przystosowania się gospodarki, czy raczej działających w niej podmiotów albo ich produkcji, do zmieniających się warunków, która pozwala utrzymać lub poprawić ich pozycję na rynku w warunkach globalnych ${ }^{3}$.

Od pojęcia konkurencyjności gospodarki narodowej należy odróżnić pojęcie międzynarodowej zdolności konkurencyjnej, którą można określić jako zdolność kraju do walki o korzyści płynące $\mathrm{z}$ udziału w międzynarodowym podziale pra$c y^{4}$. Z kolei pod pojęciem międzynarodowej pozycji konkurencyjnej rozumie się stan oraz zmiany udziałów określonego kraju w międzynarodowych obrotach towarami, usługami i czynnikami wytwórczymi, a także ewolucję struktury tych obrotów wraz z ich przemianami jakościowymis .

1 Przegląd definicji konkurencyjności gospodarki zob. np.: Macias (2006), s. 123-136; Olczyk (2006), s. 82-91.

2 Bossak, Bieńkowski (2004), s. 34.

3 Żukrowska (2002), s. 83.

4 Bossak (1984), s. 37.

5 Por. Misala (2007), s. 37. 
Pomiędzy kształtowaniem się tych trzech kategorii występują określone związki. Według Misali ${ }^{6}$ szeroko rozumiana międzynarodowa zdolność konkurencyjna określonego kraju wywiera wpływ na kształtowanie się jego międzynarodowej konkurencyjności, a ta z kolei powinna znaleźć swój wyraz w kształtowaniu się różnorodnych wskaźników, wykorzystywanych do opisu i oceny międzynarodowej pozycji konkurencyjnej kraju.

W literaturze przedmiotu dużo uwagi poświęca się czynnikom determinującym międzynarodową zdolność konkurencyjną i międzynarodową konkurencyjność krajów. Istotny wkład w rozwój tej dziedziny badań wniósł Porter. Jego koncepcję determinant konkurencyjności zwaną „diamentem Portera” uzupełnił Dunning. Z rozważań Portera i Dunninga wynika, że kluczowe znaczenie z punktu widzenia konkurencyjności mają: wyposażenie w czynniki wytwórcze, kształtowanie się rozmiarów i struktury popytu, powiązania pomiędzy różnymi gałęziami przemysłu, polityka gospodarcza państwa. Ważną rolę odgrywają również mniej lub bardziej sprzyjające zbiegi okoliczności (np. odkrycia, wynalazki, przełomowe technologie) oraz transnarodowa działalność wielkich korporacji zagranicznych, funkcjonujących na terenie danego kraju oraz krajowych poza jego granicami ${ }^{7}$.

W badaniach międzynarodowej konkurencyjności gospodarki ze względu na jej złożony charakter wykorzystuje się wiele różnorodnych czynników. Instytucje i organizacje międzynarodowe, zajmujące się ocenami konkurencyjności gospodarek konstruują własne, często bardzo złożone modele, na podstawie których prowadzą badania. Uwzględniają w nich nawet kilkaset różnych czynników, które w mniejszym lub większym stopniu wpływają na konkurencyjność badanych podmiotów.

\section{MIĘDZYNARODOWE RANKINGI KONKURENCYJNOŚCI}

Międzynarodowe rankingi konkurencyjności tworzone są na podstawie syntetycznych indeksów oceny, które konstruowane są na podstawie określonych (z założenia kompleksowych i logicznie uporządkowanych) zbiorów kryteriów. Tego typu prace prowadzone są przez różne instytucje i organizacje. Jednakże od wielu lat do najbardziej znanych i najczęściej cytowanych, zarówno przez rządy krajów, inwestorów, jak i naukowców należą raporty o konkurencyjności, publikowane przez dwie organizacje: Światowe Forum Ekonomiczne (World

\footnotetext{
${ }^{6}$ Ibidem, s. 38.

7 Cyt. za: ibidem, s. 46-82.
} 
Economic Forum) oraz Międzynarodowy Instytut Rozwoju Zarządzania (International Management Development).

Obie organizacje w swoich ocenach posługują się kompleksowymi miernikami konkurencyjności. W raportach Światowego Forum Ekonomicznego do 2005 roku wykorzystywano dwa komplementarne indeksy: Indeks Konkurencyjności Wzrostu (Growth Competitiveness Index) oraz Indeks Konkurencyjności Biznesu (Business Competitiveness Index). Od 2006 roku podstawowe znaczenie ma Globalny Indeks Konkurencyjności (Global Competitiveness Index - GCI), którego twórcą jest wybitny znawca problematyki wzrostu gospodarczego Xavier Sala-i-Martin.

Nowy bardziej kompleksowy miernik jest lepiej przystosowany do badania wielu krajów o zróżnicowanym poziomie rozwoju gospodarczego, cechujących się różnorodnością czynników wpływających na poziom ich konkurencyjności międzynarodowej. Nowa koncepcja wynika również z nowszej definicji konkurencyjności międzynarodowej, jaką przyjęło Światowe Forum Ekonomiczne. Zgodnie z nią, jest to zespół czynników, instrumentów, polityki i instytucji determinujących poziom wydajności gospodarki narodowej. Rosnąca produktywność oznacza lepsze wykorzystanie dostępnych zasobów, jest motorem stopy zwrotu z inwestycji, co z kolei wyznacza tempo wzrostu gospodarki ${ }^{8}$.

Globalny Indeks Konkurencyjności skonstruowany jest na podstawie dwunastu kategorii, które łącznie obejmują 110 czynników. Owe dwanaście kategorii tworzą następujące obszary analizy: instytucje, infrastruktura, stabilność makroekonomiczna, zdrowie i kształcenie podstawowe, kształcenie wyższe i doskonalenie zawodowe, efektywność rynków dóbr, efektywność rynku pracy, rynki finansowe, zaawansowanie technologiczne, wielkość rynku, poziom biznesu oraz innowacje.

Międzynarodowy Instytut Rozwoju Zarządzania dokonuje oceny poziomu konkurencyjności gospodarek na podstawie analizy ponad trzystu różnych kryteriów, sklasyfikowanych w czterech sekcjach, z których każda dzieli się na pięć podsekcji:

- stan gospodarki (rozwój, handel zagraniczny, inwestycje zagraniczne, zatrudnienie, ceny),

- sprawność rządu (finanse publiczne, polityka fiskalna, ramy instytucjonalne, legislacja gospodarcza, edukacja),

- efektywność biznesu (wydajność, rynek pracy, finanse, praktyki zarządzania, wpływ globalizacji),

8 Global Competitiveness Report 2006 (2006), s. 3, cyt. za: Borowski (2008), s. 84. 
- infrastruktura (infrastruktura podstawowa, technologiczna, naukowa, zdrowie i ochrona środowiska, system wartości) ${ }^{9}$.

Poszczególne podsekcje posługują się określoną, niekoniecznie taką samą, liczbą kryteriów oceny. Każdej z 20 podsekcji przypisuje się taką samą wagę (5\%) w ostatecznym wyniku.

Metodologia oceny, jaką posługują się organizacje sporządzające rankingi konkurencyjności, nie jest wolna od krytyki. Zastrzeżenia dotyczą zwłaszcza prac Międzynarodowego Instytutu Rozwoju Zarządzania. W literaturze przedmiotu ${ }^{10}$ pojawiają się zarzuty, że w raporcie nie definiuje się podstawowych pojęć i kategorii. Nie wskazuje się również na teoretyczne podstawy koncepcji metody i stosowanych miar. Brakuje rozróżnienia między konkurencyjnością o charakterze wynikowym a zdolnością konkurencyjną, czyli konkurencyjnością odnoszącej się do przyszłości. Zastrzeżenia budzi również fakt, iż podstawą oceny konkurencyjności są wskaźniki kompozytowe, będące sumą słabości i silnych stron.

W obu raportach bazuje się zarówno na tzw. „twardych danych”, jak i wynikach różnego rodzaju badań ankietowych. W odniesieniu do tych ostatnich, wskazuje się na niereprezentatywną grupę badawczą, co powoduje, że oceny nie odzwierciedlają rzeczywistej sytuacji. Szczególnie mało pochlebne opinie dotyczą Międzynarodowego Instytutu Rozwoju Zarządzania i prowadzonych przez niego badań, które sporządza się na użytek podsekcji odnoszących się funkcjonowania przedsiębiorstw, a zwłaszcza do ich sytuacji finansowej. Nie uwzględnia się w nich bowiem wielu czynników istotnych z punktu widzenia wyceny wartości przedsiębiorstw np.: wskaźników efektywności, rotacji, płynności finansowej, ryzyka działalności.

Stosowane przez Światowe Forum Ekonomiczne oraz Międzynarodowy Instytut Rozwoju Zarządzania procedury badawcze, niewątpliwie posiadają pewne mankamenty. Należy jednakże pamiętać, iż tego rodzaju badania (z założenia) służą ostatecznemu celowi, którym jest dostarczenie odbiorcy szybkiej i syntetycznej oceny konkurencyjności określonej gospodarki, w postaci konkretnej pozycji zajmowanej w rankingu kilkudziesięciu krajów. Jednocześnie warto zaznaczyć, że owe raporty pozwalają na głębszą analizę przyczyn, które zadecydowały o pozycji określonego kraju w rankingu. Skoro tak się dzieje, to nie można zaprzeczyć, iż wzbogacają one wiedzę na temat konkurencyjności krajów na arenie międzynarodowej.

\footnotetext{
9 Szerzej na ten temat zob.: Borowski (2008), s. 86-88.

10 Bossak (2006), s. 260-261.
} 


\section{KONKURENCYJNOŚĆ REPUBLIKI CZESKIEJ WEDŁUG OCEN ŚWIATOWEGO FORUM EKONOMICZNEGO I MIĘDZYNARODOWEGO INSTYTUTU ROZWOJU ZARZĄDZANIA}

Wyniki badań Światowego Forum Ekonomicznego (WEF) i Międzynarodowego Instytutu Rozwoju Zarządzania (IMD) wykazują dużą zbieżność, jeśli chodzi o wskazanie najbardziej konkurencyjnej gospodarki świata. Stany Zjednoczone zajęły w latach 2007-2008 pierwsze miejsce w obu rankingach (zob. tabela 1). Na tak wysoką pozycję wpłynęły cechy charakterystyczne gospodarki amerykańskiej oraz jej duże umiędzynarodowienie zwłaszcza w obrocie kapitałowym. Jest to kraj, który przoduje w niezwykle istotnym obszarze, jakim są innowacje. Dobrze oceniana jest również infrastruktura oraz efektywność rynków dóbr i pracy. Pozycja Stanów Zjednoczonych jest jednak zagrożona, głównie za sprawą kryzysu gospodarczego. W trzecim kwartale 2008 roku gospodarka amerykańska „skurczyła się" o $0,3 \%$, a bezrobocie wyniosło aż 6,5\% ${ }^{11}$. Bardzo źle oceniana jest polityka makroekonomiczna, która przez wiele lat łączyła wysoki deficyt budżetu ze zbyt luźną polityką monetarną. Naprawa gospodarki amerykańskiej w sytuacji rosnącego bezrobocia, spadającej sprzedaży oraz malejących zysków przedsiębiorstw staje się zatem coraz pilniejsza.

Bardzo wysokim poziomem konkurencyjności charakteryzują się gospodarki azjatyckie, takie jak: Singapur, Hong-Kong, które wyróżniają się pod względem jakości otoczenia instytucjonalnego, infrastruktury, efektywności rynków, zaawansowania technologicznego. Wysoki poziom kapitału ludzkiego w tych krajach przyczynia się do wzrostu ich innowacyjności.

Z obydwu rankingów wynika, iż pozycja konkurencyjna Republiki Czeskiej poprawiła się w pierwszych latach członkostwa w Unii Europejskiej. W 2004 roku kraj ten plasował się na 40. miejscu w rankingu WEF i 36. w rankingu IMD. W 2006 roku Czechy zajęły już 29. pozycję według oceny WEF i 28. według IMD, a dwa lata później notowane były odpowiednio na 33. i 28 . pozycji (zob. tabela 1). Wynik ten można uznać za stosunkowo dobry, zważywszy na fakt, iż kraje o podobnym poziomie rozwoju gospodarczego, które również przeszły drogę transformacji systemowej i w 2004 roku stały się członkiem Unii Europejskiej, zajęły w omawianych rankingach dalsze lokaty. Na przykład Słowacja w 2008 roku plasowała się na 46. pozycji według WEF i na 30. według IMD, Węgry na 62. w rankingu WEF (według IMD na 38.), a Polska na 53. we-

11 Prusek (2008), s. 27. 
Tabela 1. Pozycja Republiki Czeskiej w badaniach światowej konkurencyjności według oceny Światowego Forum Ekonomicznego (WEF) oraz Międzynarodowego Instytutu Rozwoju Zarządzania (IMD) w latach 2003-2008

\begin{tabular}{|c|c|c|c|c|}
\hline Rok & $\begin{array}{c}\text { Miejsce Republiki } \\
\text { Czeskiej } \\
\text { w rankingu WEF }\end{array}$ & $\begin{array}{c}\text { Kraje przodujące } \\
\text { w konkurencyjności } \\
\text { wg WEF }\end{array}$ & $\begin{array}{c}\text { Miejsce Republiki } \\
\text { Czeskiej } \\
\text { w rankingu IMD }\end{array}$ & $\begin{array}{c}\text { Kraje przodujące } \\
\text { w konkurencyjności } \\
\text { wg IMD }\end{array}$ \\
\hline 2003 & 39 & $\begin{array}{c}\text { Finlandia } \\
\text { Stany Zjednoczone }\end{array}$ & 31 & $\begin{array}{c}\text { Stany Zjednoczone } \\
\text { Luksemburg }\end{array}$ \\
\hline 2004 & 40 & $\begin{array}{c}\text { Finlandia } \\
\text { Stany Zjednoczone }\end{array}$ & 36 & $\begin{array}{c}\text { Stany Zjednoczone } \\
\text { Singapur }\end{array}$ \\
\hline 2006 & 29 & $\begin{array}{c}\text { Finlandia } \\
\text { Stany Zjednoczone }\end{array}$ & 30 & $\begin{array}{c}\text { Stany Zjednoczone } \\
\text { Hong-Kong }\end{array}$ \\
\hline 2007 & 33 & $\begin{array}{c}\text { Szwajcaria } \\
\text { Finlandia }\end{array}$ & 28 & $\begin{array}{c}\text { Stany Zjednoczone } \\
\text { Hong-Kong }\end{array}$ \\
\hline 2008 & 33 & $\begin{array}{c}\text { Stany Zjednoczone } \\
\text { Szwajcaria }\end{array}$ & 32 & $\begin{array}{c}\text { Stany Zjednoczone } \\
\text { Singapur }\end{array}$ \\
\hline
\end{tabular}

* W pracach WEF badano konkurencyjność większej liczby krajów niż w pracach IMD. W 2008 r. ranking WEF uwzględniał 134 kraje, natomiast IMD zbadał i ocenił 55 gospodarek.

Źródło: Global Competitiveness Report, za lata 2003-2008, World Economic Forum, Geneva; World Competitiveness Yearbook, za lata 2003-2008, International Management Development, Lausanne.

dług WEF i 44. pozycji w rankingu IMD ${ }^{12}$. Wśród krajów UE Republika Czeska, zajmuje środkowe lokaty (zob. tabela 2). Oceniana jest jako bardziej konkurencyjna niż pozostałe kraje nowej Unii Europejskiej (wyjątek stanowi Estonia). Czechy wyprzedzają także inne kraje, które znacznie wcześniej stały się członkami Unii Europejskiej, np.: Portugalię, Grecję, Włochy. Warto jednakże podkreślić, że dystans, jaki dzieli Republikę Czeską i najbardziej konkurencyjne gospodarki w Europie, czyli kraje skandynawskie, Niemcy, Wielką Brytanię czy kraje Beneluksu, jest jeszcze spory.

Według Światowego Forum Ekonomicznego, można wyróżnić trzy stadia rozwoju gospodarki. W początkowym stadium o konkurencyjności gospodarki przesądzają czynniki wytwórcze. Kluczowe znaczenie ma wyposażenie kraju w zasoby taniej siły roboczej oraz zasoby naturalne. Firmy konkuruja przede wszystkim cena, sprzedając produkty o niskim stopniu przetworzenia. $\mathrm{W}$ tej fazie kluczową rolę, z punktu widzenia konkurencyjności gospodarki, pełnią: stabilność makroekonomiczna, sprzyjające otoczenie instytucjonalne, infrastruktura

12 Tak duże rozbieżności w zajmowanych pozycjach są konsekwencją nie tylko różnej metodologii pomiaru konkurencyjności w obu instytucjach, ale także różnej liczby badanych gospodarek. 
Tabela 2. Konkurencyjność międzynarodowa krajów członkowskich Unii Europejskiej objętych badaniami WEF i IMD w 2008 roku.

\begin{tabular}{|l|c|c|l|c|c|}
\hline $\begin{array}{l}\text { Pozycja kraju w UE } \\
\text { wg rankingu WEF }\end{array}$ & $\begin{array}{c}\text { Pozycja kraju } \\
\text { w świecie } \\
\text { wg rankingu }\end{array}$ & $\begin{array}{c}\text { Liczba } \\
\text { punktów } \\
\text { (maksymalna } \\
\text { liczba=7) }\end{array}$ & $\begin{array}{l}\text { Pozycja kraju w UE } \\
\text { wg rankingu IMD }\end{array}$ & $\begin{array}{c}\text { Pozycja kraju } \\
\text { w świecie } \\
\text { wg rankingu }\end{array}$ & $\begin{array}{c}\text { Liczba } \\
\text { punktów } \\
\text { (maksymalna } \\
\text { liczba=100) }\end{array}$ \\
\hline 1. Dania & 3 & 5,58 & 1. Luksemburg & 5 & 84,405 \\
2. Szwecja & 4 & 5.53 & 2. Dania & 6 & 83,852 \\
3. Finlandia & 6 & 5,50 & 3. Szwecja & 9 & 82,464 \\
4. Niemcy & 7 & 5,46 & 4. Holandia & 10 & 80,476 \\
5. Holandia & 8 & 5,41 & 5. Irlandia & 12 & 77,638 \\
6. Wielka Brytania & 12 & 5,30 & 6. Austria & 14 & 75,028 \\
7. Austria & 14 & 5,23 & 7. Finlandia & 15 & 75,025 \\
8. Francja & 16 & 5,22 & 8. Niemcy & 16 & 74,735 \\
9. Belgia & 19 & 5,14 & 9. Wielka Brytania & 21 & 71,904 \\
10. Irlandia & 22 & 4,99 & 10. Estonia & 23 & 69,648 \\
11. Luksemburg & 25 & 4,85 & 11. Belgia & 24 & 68,746 \\
12. Hiszpania & 29 & 4,72 & 12. Francja & 25 & 66,012 \\
13. Estonia & 32 & 4,67 & 13. Republika & $\mathbf{2 8}$ & $\mathbf{6 2 , 2 4 7}$ \\
14. Republika & 33 & 4,62 & Czeska & & \\
$\quad$ Czeska & & & 14. Słowacja & 30 & 59,365 \\
15. Cypr & 40 & 4,53 & 15. Słowenia & 32 & 57,904 \\
16. Słowenia & 42 & 4,50 & 16. Hiszpania & 33 & 57,515 \\
17. Portugalia & 43 & 4,47 & 17. Litwa & 36 & 56,234 \\
18. Litwa & 44 & 4,45 & 18. Portugalia & 37 & 54,657 \\
19. Słowacja & 46 & 4,40 & 19. Węgry & 38 & 52,932 \\
20. Włochy & 49 & 4,35 & 20. Bułgaria & 39 & 51,392 \\
21. Malta & 52 & 4,31 & 21. Grecja & 42 & 48,761 \\
22. Polska & 53 & 4,28 & 22. Polska & 44 & 47,986 \\
23. Łotwa & 54 & 4,26 & 23. Rumunia & 45 & 47,549 \\
24. Węgry & 62 & 4,22 & 24. Włochy & 46 & 46,921 \\
25. Grecja & 67 & 4,11 & & & \\
26. Rumunia & 68 & 4,10 & & & \\
27. Bułgaria & 76 & 4,03 & & & \\
\hline
\end{tabular}

* Trzy kraje UE nie były objęte badaniem IMD.

Źródło: opracowanie własne na podstawie: World Competitiveness Yearbook 2008, International Management Development, s. 13, The Global Competitiveness Report 2008-2009, World Economic Forum, Geneva 2008, s. 10.

techniczna i jakość kapitału ludzkiego, rozumiana jako zdrowie i kształcenie na poziomie podstawowym. W kolejnym stadium rozwoju gospodarki podkreśla się rolę efektywności. Podstawowe znaczenie ma stosowanie nowszych, wydajniejszych technologii produkcji. Firmy konkurują nie tylko cena, ale także jakością oferowanych produktów. W tej fazie podkreśla się rolę efektywności rynków (dóbr, pracy i finansowych) oraz dostępności wysokiej jakości kapitału ludzkiego. Ową dostępność warunkuje system kształcenia na poziomie wyższym 
i doskonalenia zawodowego. $\mathrm{W}$ ostatnim stadium rozwoju, w kontekście konkurencyjności gospodarki kluczowego znaczenie nabiera jej innowacyjność. Istotne staje się stosowanie najnowocześniejszych metod wytwarzania i wprowadzanie innowacji, które są wynikiem rozwoju nowej wiedzy. Kluczowe znaczenie ma zatem działalność badawczo-rozwojowa, czyli sektor, który zajmuje się tworzeniem i rozprzestrzenianiem nowej wiedzy, w celu lepszego wykorzystania istniejących zasobów.

Według Światowego Forum Ekonomicznego, czeska gospodarka weszła już w stadium rozwoju opartym na innowacyjności (zob. rys. 1). Jest wprawdzie dopiero na początku tej drogi umacniania swojej pozycji konkurencyjnej, ale dla porównania polska gospodarka jest ciagle $\mathrm{w}$ fazie przechodzenia ze stadium opartym na efektywności do stadium opartym na innowacyjności.
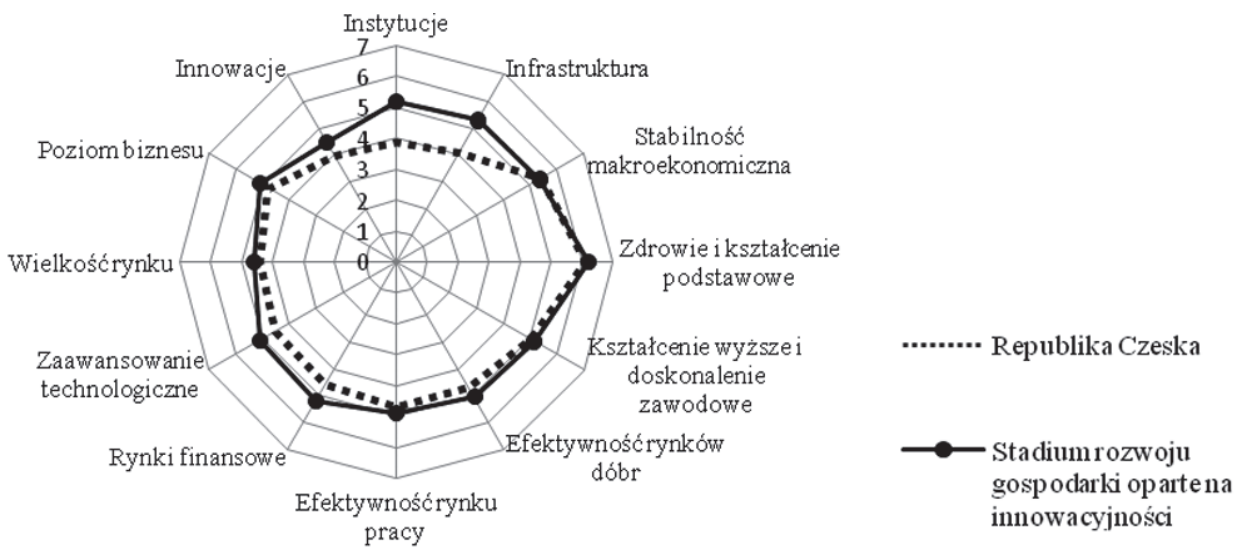

Rys. 1. Ocena konkurencyjności Republiki Czeskiej w poszczególnych kategoriach w 2008 roku według Światowego Forum Ekonomicznego

Źródło: The Global Competitiveness Report 2008-2009, World Economic Forum, Geneva 2008, s. 146.

W kategoriach innowacje oraz kształcenie wyższe i doskonalenie zawodowe Czechy zdobyły wysoką - 25. pozycję wśród 134 ocenianych gospodarek (zob. tabela 3). Dużą rolę w ramach tych kategorii odegrały: wysoki poziom kształcenia wyższego, zwłaszcza w zakresie nauk ścisłych i przyrodniczych, dostępność naukowców i inżynierów, stosunkowo duże wydatki przedsiębiorstw na działalność badawczo-rozwojową, a także wysoka jakość instytutów badawczych oraz ich współpraca z przemysłem.

Wyniki WEF potwierdzają również raporty IMD oraz Centrum Technologicznego Czeskiej Akademii Nauk (Technologické centrum, Akedemie věd $\check{C} R$ ). Po akcesji do UE nastapiła poprawa pozycji Czech w zakresie infrastruktury 
Tabela 3. Pozycja Republiki Czeskiej w poszczególnych kategoriach konkurencyjności w 2008 roku, według oceny Światowego Forum Ekonomicznego (WEF)

\begin{tabular}{|l|c|c|}
\hline \multicolumn{1}{|c|}{ Kategorie konkurencyjności wg WEF } & $\begin{array}{c}\text { Pozycja w rankingu } \\
\text { wyznaczona tym czynnikiem }\end{array}$ & $\begin{array}{c}\text { Liczba punktów } \\
\text { (maksymalna liczba=7) }\end{array}$ \\
\hline Instytucje & 72 & 3,87 \\
Infrastruktura & 50 & 4,11 \\
Stabilność makroekonomiczna & 42 & 5,37 \\
Zdrowie i kształcenie podstawowe & 29 & 6,07 \\
Kształcenie wyższe i doskonalenie zawodowe & 25 & 4,98 \\
Efektywność rynków dóbr & 33 & 4,73 \\
Efektywność rynku pracy & 28 & 4,74 \\
Rynki finansowe & 47 & 4,65 \\
Zaawansowanie technologiczne & 33 & 4,48 \\
Wielkość rynku & 38 & 4,45 \\
Poziom biznesu & 29 & 4,77 \\
Innowacje & 25 & 3,98 \\
\hline
\end{tabular}

Źródło: The Global Competitiveness Report 2008-2009, World Economic Forum, Geneva 2008, s. 146.

naukowej, wzrosły wydatki na badania i rozwój oraz rola instytutów badawczych, zacieśniła się współpraca naukowców i przedsiębiorców. 43,2\% czeskich pracowników naukowych reprezentuje nauki techniczne, w przeszło $70 \%$ są oni zatrudnieni w sektorze przedsiębiorstw, zwłaszcza w przemysłach wysokiej i średniej techniki ${ }^{13}$. Warto również dodać, że z nowych krajów Wspólnoty Republika Czeska ma jedną z lepiej ocenianych strukturę finansowania wydatków na B+R. Wyraża się ona większym zaangażowaniem sektora prywatnego na rzecz zmniejszenia, do około $40 \%$, udziału środków budżetowych. Jest to wynik gorszy niż w większości starych krajach UE, gdzie sektor publiczny pokrywa tylko około 1/3 ogółu wydatków na B+R, ale znacznie lepszy niż w innych, nowych krajach UE, takich jak Polska, Węgry, Estonia, Litwa, Łotwa czy Cypr. Środki publiczne stanowią tam ponad $60 \%$ wydatków na działalność badawczo-rozwojową ${ }^{14}$.

Dobre oceny Republika Czeska notuje także w kategorii zdrowie i kształcenie podstawowe (29. pozycja w rankingu WEF). Trzeba jednak zaznaczyć, że w ramach tego obszaru analizy badano wpływ na biznes takich czynników, z którymi Czechy nigdy nie miały większych problemów, jak np.: choroby typu malaria, gruźlica, HIV/Aids, powszechność i jakość kształcenia podstawowego.

Oceny międzynarodowej pozycji konkurencyjnej Republiki Czeskiej byłby lepsze gdyby nie słabości niektórych obszarów. Dotyczy to w szczególności

13 Klusáček, Kučera, Pazour, (2008), s. 67.

14 Weresa (red.) (2006), s. 167. 
infrastruktury instytucjonalnej, która została sklasyfikowana w rankingu WEF na 72. pozycji (3,87 punktu). Wśród czynników, które przesądzają o słabej ocenie otoczenia instytucjonalnego wymieniane są: brak zaufania do polityków, mało przejrzysta polityka rządu, biurokracja, decyzje uznaniowe urzędników, marnotrawstwo środków publicznych, korupcja. Negatywnie oceny dotyczą także funkcjonowania policji i wymiaru sprawiedliwości.

Elementów potwierdzających niekorzystną sytuację w obszarze infrastruktury instytucjonalnej można się doszukać także w innych opracowaniach, na przykład w Raporcie Banku Światowego Doing Business in 200915. Według syntetycznej oceny swobody prowadzeniu działalności gospodarczej, Czechy znalazły się na 75. pozycji (na 181 badanych krajów). W dużym stopniu było to związane z wadliwym funkcjonowaniem otoczenia instytucjonalnego biznesu. Republikę Czeską szczególnie źle oceniono w kategorii „płacenie podatków” (118. miejsce). Zgodnie z szacunkami autorów raportu przedsiębiorca, który chce spełniać wymagania czeskich przepisów podatkowych musi dokonać 12 płatności, składających się w sumie na 48,6\% zysku brutto. Podobnie słabo wypadają Czechy w kategoriach „rozpoczynanie działalności gospodarczej”16 - 86. pozycja i „zamykanie działalności gospodarczej” - 113. Na niską ocenę składają się takie czynniki, jak: wysoki koszt oraz duża liczba formalności. Czechy są także jednym z najgorzej ocenianych krajów w Europie (95. miejsce w rankingu cząstkowym), jeśli chodzi o czas potrzebny na egzekwowanie należności z umów - 820 dni, doliczono się ponadto 27 formalności, jakie trzeba przy tym dopełnić ${ }^{17}$.

$\mathrm{Na}$ tle innych gospodarek światowych, nie są też najlepiej oceniane wyniki makroekonomiczne czeskiej gospodarki, głównie z powodu zbyt dużego deficytu budżetowego, wysokiego długu publicznego, relatywnie niskich oszczędności gospodarstw domowych. Kolejnym obszarem, którego oceny nie są zadowalające, są rynki finansowe (49. pozycja w rankingu WEF; 4,65 punktu), a w szczególności, ochrona inwestorów, jakość systemu bankowego, dostęp do kredytów, dostęp do venture capital. Sektor usług finansowych w Republice Czeskiej został nisko oceniony również w raporcie dotyczącym realizacji Strategii Lizbońskiej ${ }^{18}$.

15 Raport ten ocenia otoczenie regulacyjne dla inwestorów w okresie 01.07.2007 r. 30.06.2008 r. (tj. w trakcie roku finansowego Banku Światowego).

16 Analizowano działalność gospodarczą prowadzoną w formie spółki z ograniczoną odpowiedzialnością.

17 Szerzej na temat swobody prowadzenia działalności gospodarczej w Republice Czeskiej zob.: Doing Business in 2009 (2008).

18 W Strategii Lizbońskiej UE określiła główny cel i priorytety swojego rozwoju do $2010 \mathrm{r}$. Cel ten sformułowano następująco: „Budowa w Europie najbardziej konkurencyjnej i dynamicznej gospodarki na świecie, opartej na wiedzy, a zarazem zdolnej do systematycznego wzrostu gospodarczego, zapewniającej większą liczbę miejsc pracy w warunkach większej spójności społecznej i respektowania zasad zrównoważonego rozwoju”. 
Jakość tego typu usług w Czechach oceniono bowiem poniżej średniej unijnej (19. pozycja wśród 27 badanych krajów UE) ${ }^{19}$.

Słabe oceny dotyczą także infrastruktury technicznej, która została sklasyfikowana na 50. pozycji (4,11 punktu). W tym obszarze największym problemem jest jakość infrastruktury drogowej.

W obszarze analizy ogólnie nazwanym „wielkość rynku” Republika Czeska także nie ma zbyt wysokich notowań (38. pozycja), niemniej jednak należy zwrócić uwagę na fakt, iż w ramach tej kategorii niekorzystne oceny dotyczą jednej z subkategorii tzn. wielkości rynku wewnętrznego, natomiast zaangażowanie Czech w sprzedaż na rynkach zagranicznych jest postrzegane przez autorów raportu jako przewaga konkurencyjna. Istotnie handel zagraniczny jest dziedziną, z którą gospodarka czeska radzi sobie całkiem dobrze, od 2005 roku notuje bowiem dodatnie saldo bilansu handlowego. W 2007 roku wynosiło ono ponad 3 mln EUR $^{20}$.

\section{PODSUMOWANIE}

Republika Czeska jest w rankingach konkurencyjności gospodarek jednym z wyżej notowanych krajów, wśród tych, które przeszły drogę transformacji systemowej i stały się w 2004 roku członkiem Unii Europejskiej. Według Światowego Forum Ekonomicznego, Czechy są obecnie 33. gospodarką świata, dla porównania Polska - 53. Światowe rankingi pokazują, że Republika Czeska stosunkowo dobrze radzi sobie z nadrabianiem zaległości w obszarze innowacji, choć niwelowanie różnic w tym zakresie nie jest procesem szybkim. Dobrze oceniana jest również jakość kształcenia podstawowego i wyższego oraz doskonalenie zawodowe.

Negatywne czynniki wpływające na obecną konkurencyjność czeskiej gospodarki tylko po części można wiązać z przeszłością gospodarki planowanej. Źródeł wielu z nich należy poszukiwać w niezbyt odległej przeszłości i teraźniejszości. Do nich należą przede wszystkim te, które ograniczają swobody gospodarcze, jak: biurokracja, korupcja, mało przejrzysta polityka gospodarcza kolejnych rządów. Gospodarka czeska ma w przyszłości szansę znacznie podnieść swoją konkurencyjność, pod warunkiem, że będzie poprawiać sytuację w tych obszarach, w których obecnie notuje słabe wyniki (np. infrastruktura instytucjonalna i techniczna, stabilność makroekonomiczna) i dodatkowo umacniać swoje przewagi konkurencyjne w obszarach, w których już teraz jest stosunkowo dobra.

19 The Lisbon Review 2008. Measuring Europe's Progress In Reform, World Economic Forum, Geneva 2008, www.weforum.org.

20 Zahranični obchod České republiky 2007 (2008), s. 32. 


\section{LITERATURA}

Borowski J. (2008), Globalizacja, konkurencyjność i międzynarodowe strategie przedsiębiorstw, Wydawnictwo Uniwersytetu w Białymstoku, Białystok.

Bossak J. W. (1984), Społeczno-ekonomiczne uwarunkowania międzynarodowej zdolności konkurencyjnej gospodarki Japonii, Monografie i Opracowania nr 153, SGPiS, Warszawa.

Bossak J. W., W. Bieńkowski, Międzynarodowa zdolność konkurencyjna kraju i przedsiębiorstw. Wyzwania dla Polski na progu XXI wieku, Szkoła Główna Handlowa, Warszawa 2004.

Bossak J. (2006), Teoria i metodologia. Krytyczna ocena stosowanych metod analizy, [w:] M. A. Weresa (red.), Polska. Raport o konkurencyjności 2006. Rola innowacji w kształtowaniu przewag konkurencyjnych, Szkoła Główna Handlowa, Warszawa.

Doing Business in 2009. Country profile for Czech Republic (2008), World Bank, www.doingbusiness.org.

Klusáček K., Kučera Z., Pazour M. (2008), Zelená kniha výzkumu, vývoje a inovacív České republice. Analytická část, Technologické centrum, Akedemie věd ČR, Praha.

Macias J. (2006), Konkurencyjność gospodarki-zagadnienia terminologiczne i metodologiczne, „Gospodarka w Praktyce i Teorii”, nr 2.

Misala J. (2007), Międzynarodowa zdolność konkurencyjna i międzynarodowa konkurencyjność gospodarki narodowej. Podstawy teoretyczne, Wydawnictwo Politechniki Radomskiej, Radom.

Olczyk M. (2006), Konkurencyjność - spór wokół definicji, „Gospodarka w Praktyce i Teorii", $\mathrm{nr} 1$.

Prusek T., Gospodarka USA zmierza do recesji, „Gazeta Wyborcza” z dnia 31.10.2008 r.

The Global Competitiveness Report 2008-2009 oraz lata wcześniejsze, World Economic Forum, Geneva.

The Lisbon Review 2008. Measuring Europe's Progress In Reform (2008), World Economic Forum, Geneva, www.weforum.org.

Weresa M. A. (red.) (2006), Polska. Raport o konkurencyjności 2006. Rola innowacji w kształtowaniu przewag konkurencyjnych, Oficyna Wydawnicza Szkoły Głównej Handlowej, Warszawa.

World Competitiveness Yearbook 2008 oraz lata wcześniejsze, International Management Development, Lausanne.

Zahranični obchod České republiky 2007 (2008), Ministerstvo průmyslu a obchodu, Český statistický úřad, Praha.

Żukrowska K. (2002), Konkurencyjność systemowa w procesie transformacji. Przykład Polski, [w:] J. Bossak, W. Bieńkowski (red.), Konkurencyjność gospodarki Polski $w$ dobie integracji z Uniq Europejskq i globalizacji, SGH, Warszawa. 


\section{COMPETITIVENESS OF CZECH ECONOMY IN THE LIGHT OF INTERNATIONAL RANKINGS}

A b stract. The aim of this study is to show a competitive profile of Czech Republic. In the world rankings of competitiveness, Czech Republic is classified higher than other countries which underwent system transformation and became members of the European Union. According to World Economic Forum, Czech Republic has become thirty third world economy (out of 134 countries rated), according to International Management Development the country in question is ranked twenty eighth. Competitiveness of Czech economy is affected positively by factors such as innovations, foreign direct investment and higher education and training. The position of Czech Republic would be much higher if it were not for its weaknesses that exposed in some categories analyzed. They concern mainly technical and institutional infrastructure. Financial services sector quality and macroeconomic stability are also rated relatively low.

K e y w o r d s : competitiveness, rankings of competitiveness. 